
ІМПРОВІЗАЦІЙНІ САМОДІЯЛЬНІ ХОРИ В КОНТЕКСТІ
СУЧАСНОЇ МУЗИЧНОЇ КУЛЬТУРИ УКРАЇНИ

\title{
IMPROVIZATIONAL ASSEMBLY CHOIRS IN THE CONTEXT OF MODERN MUSICAL CULTURE OF UKRAINE
}

\begin{abstract}
1з самого початку самодіяльне хорове мистецтво відігравало вагому роль у прочесі публічної та культурної експозиції. Однак сучасні умови культурних прочесів потребують додаткової уваги до аматорського хорового мистецтва в системі української культури. У статті намагаються проаналізувати діяльність імпровізаційної аматорської вокально-хорової практики в контексті сучасної музичної культури України. Наведено загальну характеристику народної поліфонії, проаналізовано роль імпровізації в аматорському хоровому виконанні. Визначено якісні критерії імпровізаційного самодіяльного народного хору. На прикладі етнограсрічного хору «Гомон» імені Леопольда Ященка проаналізовано роль аматорського хору в сучасній виконавській практиці. В умовах теперішнього часу, коли модернізація громадського та культурного життя виходить на перший план, існує думка, що народне хорове мистецтво втрачає культурну потенційність. Однак, незважаючи на значний розвиток сучасності, що суттєво впливає на сореру культури, на людину, їи властиве тяжіння не лише до технічного, а й до духовного прогресу. Так, народне хорове мистецтво й сьогодні залишається одним із засобів духовного розвитку та виховання суспільства. Особливості функціонування аматорського хорового колективу розглядаються з урахуванням кількості учасників і можливостей проведення виступів. Визначено головне призначення самодіяльного хору, що полягає в підтримці традицій масового співу, що втрачається нині серед музично-технічних засобів. Наші мелодійно обдаровані люди 3 творців пісенної та музичної культури переростають у їі пасивних споживачів. Середовище хору «Гомон» - одна з форм протидї паралізуючому впливу художньої служби, тому Леопольд Іванович постійно піклувався про розширення співочого кола і щедро ділився репертуаром з іншими колективами: пісні на те й пісні, щоб люди їх співали.

Ключові слова: спів, народні виступи, імпровізація, самодіяльний народний хор, народні голоси.
\end{abstract}

УДК 784.4(398.8)

2019-17-2-17

\section{Власова С.А.,}

старший викладач

кафедри музичного мистецтва

Київського національного університету

культури і мистецтв
From the beginning an amateur choral art played a ponderable role in the process of public and cultural exposure. However, the modern terms of cultural processes require additional attention to the amateur choral art in the system of the Ukrainian culture. The article attempts to analyze the activity of improvisational amateur vocal-choral practice in the context of contemporary musical culture of Ukraine. The general characteristics of folk polyphony are given, the role of improvisation in amateur choral performance is analyzed. The qualitative criteria of improvisational amateur folk choir are determined. An example of the ethnographic choir "Gomon" named after Leopold Yashchenko analyzes the role of an amateur choir in contemporary performing practice. In the conditions of present time, when modernisation of public and cultural life goes out on the first plan, an idea exists, that a folk choral art loses the cultural ponderability. However, in spite of the considerable development of modernity, which significantly influences the sphere of culture, on the person, it is inherently attracted not only to technical but also to spiritual progress. Yes, folk choral art and today it remains to one of facilities of spiritual development and education of society. The features of functioning of amateur choral collective are examined in the context of amount of participants and them carrying out possibilities. The primary purpose of amateur choir, that consists in there was maintenance of traditions of the mass singing, that is lost presently among music and technical facilities, is determined. Our the melodious, gifted people from the creators of song and musical culture grow into her passive consumers. Environment of choir of "Gomon" - one of forms of counteraction to paralysing influence of artistic service; therefore Leopold Ivanovich constantly cared of expansion of singing circle and generously divided by a repertoire with other collectives are songs on that and songs, that people sang them.

Key words: singing, folk performances, improvisation, amateur folk choir, folk voices.
Постановка проблеми в загальному вигляді. Сучасні умови технічного та наукового прогресу висувають особливі вимоги до всіх галузей культури, зокрема й до самодіяльного народного хорового мистецтва, до його специфрічних виконавських якостей і різноманітних умов побутування.

Аналіз останніх досліджень і публікацій. Питання наукового осмислення українського народного хорового мистецтва привертає увагу багатьох дослідників. В аспекті проблеми трансформації музичної культури, зокрема хорового мистецтва, найбільш цікавою $€$ праця І. Бермес «Український хоровий рух у контексті соціокультурних процесів XIX - початку XXI століття», де досліджено становлення та розвиток українського хорового руху XIX - початку XXI ст., розкрито ментальні й історичні підвалини хорового мистецтва України, сутнісні особливості українського хорового руху як соціокультурного френомену [1]. У роботі М. Гуць «Прапороносець відродження українського народного співу у Києві (до 75-річчя від дня народження Леопольда Ященка)» висвітлено життєвий і творчий шлях Л. Ященка - фольклориста, диригента, композитора, музиканта, поета-лірика, співака, а також засновника й керівника етнографрічного хору української народної пісні «Гомін», головна мета якого - відродження народних традицій, звичаїв та обрядів [2]. У статті О. Скопцової «Формування організаційних, художніх та стилістичних особливостей українського 
народного хорового виконавства кінця XIX - першої третини $X X$ ст.» розглянуто питання становлення й розвитку народного хорового мистецтва, виникнення аматорських народних хорових колективів, ранніх професійних народних хорових колективів, визначено їхню роль в еволюції народного хорового мистецтва [3]. О. Сможаник у роботі «Джерела української хорової культури» підсумовує, що хорове багатоголосся завжди було тісно пов'язане $з$ народною творчістю та фрормувалося на прадавніх зразках пісенної культури й церковної музики, воно є невіддільною частиною народного побуту [4].

Виділення не вирішених раніше частин загальної проблеми. Сучасна виконавська практика галузі хорового мистецтва зумовлює відповідну тенденцію модернізації процесу сценічного втілення народної пісні. Так, вимоги до концертуючого хорового колективу стають більш жорсткими в контексті організації та проведення концертних заходів у поєднанні із сучасним матеріально технічним забезпеченням. Також суворішими стають виконавські та зовнішньоестетичні виміри. Отже, перед самодіяльними хоровими колективами постає низка умов, спрямованих на задоволення глядацького попиту. Так, концертуючі самодіяльні хорові колективи зазнають трансформаційних процесів в умовах репетиційної та концертновиконавської діяльності.

Мета статті - визначити роль самодіяльних хорових колективів в умовах сучасної музичної культури України (на прикладі етнографрічного хору «Гомін»).

Виклад основного матеріалу. В умовах сьогодення, коли модернізація суспільного та культурного життя виходить на перший план, побутує думка, що народне хорове мистецтво втрачає свою культурну вагомість. Проте, незважаючи на значний розвиток науки й техніки, що суттєво впливає й на сфреру культури, людині властиве від природи не лише тяжіння до технічного, а й духовного прогресу. Так, народне хорове мистецтво й сьогодні залишається одним із засобів духовного розвитку та виховання суспільства.

Основними ознаками народнопісенного виконавського процесу $€$ усність і колективність. Ці ознаки відіграють важливу роль у визначенні народної пісні як завершеного мистецького жанру. Цілком зрозуміло, що пісенна спадщина, котра створюється й удосконалюється колективно протягом тривалого часу самим народом, відрізняється цілковитою відповідністю соціокультурним і художньо-естетичним потребам соціуму за своєю формою та змістом. Проте актуальність народної пісні не варто розуміти як константний фрактор. Завершеність музичного твору несе в собі відносний характер і залежить значною мірою від умов і середовища його побутування. Кожен музичний твір передусім найкраще розкривається в системі побутування своїх регіональних локальних виконавських традицій [4].

Отже, колективи, котрі беруть за репертуарне підґрунтя українське народне багатоголосся, в основі самодіяльні: у них може брати участь кожен, хто має музичний слух і голосові дані. Якправило, таким колективом керує найбільш здібний та ініціативний виконавець-заспівувач. Він найкраще за інших відчуває зміст і характер пісні, легко знаходить комфортну тональність і значно впливає на інтерпретаційний контекст у процесі виконання [3].

Під час виконання народного багатоголосся відсутній поділ на зрівноважені хорові партії, як це прийнято в профресійному (навчально-профресійному народному, або академічному) хорі. Так, співаки з більш розвиненими вокальними здібностями мають фрункції заспівувача та вивідника, решта співає в унісон або поділяється на партії за принципом випадкової розбіжності голосів. На заспівувача й вивідника покладається роль імпровізатора-інтерпретатора, тобто фрункція творення художнього змісту музичного твору та підпорядкування загального процесу єдиній творчій концепції. Така потреба викликана наявністю окремих співаків-імпровізаторів (крім заспівувача та вивідника), котрі за допомогою прийомів імпровізаційного розспівування створюють окремі хорові партії, котрі потребують узгодження із загальною виконавською концепцією [3].

Отже, мистецтво імпровізації відіграє важливу роль у народному багатоголоссі, як наслідок, і в професійному народному хоровому мистецтві. У виконавській практиці закріпилися характерні прийоми вільного розспівування основної мелодії й підголоска пісні, від чого музичний твір збагачується та з'являється низка його варіацій. Такі засоби допомагають не лише створювати нові музичні твори, а й поглиблювати трактування вже наявних і відомих музичних творів. Так, якісним критерієм вокальної народнопісенної імпровізації $€$ потреба високого відчуття міри, тонке відчуття локальної регіональної виконавської специфріки. Отже, імпровізація в народному хоровому мистецтві $€$ основним методом поглиблення художнього трактування музичного твору в процесі його засвоєння та відтворення. Цим підтверджується визначення народного хору (як самодіяльного, так і профресійного) не лише як виконавського, а і як творчого колективу, адже творча ініціатива виконавців виявляється саме в процесі імпровізації. У свою чергу, якісна імпровізація виникає на основі досвіду й майстерності виконавців [2].

У виконавській практиці як особливому критерії виконавського процесу народне хорове мистецтво вирізняється, зокрема, і своєрідним звучанням голосів. Побутує хибна думка, що «пронизливий», «верескливий», «напружений» звук є характерним 
для народної манери співу. Прихильники цього погляду хибно визначають «вульгарну» манеру співу як народну. У цьому контексті звукоутворення значною мірою залежить від того, в яких умовах виконується пісня. Тобто, якщо взяти до увагу певне змішування регіональних традицій за рахунок цікавості до репертуару інших регіональних традицій, вагомим чинником постає саме місце виконання пісні. Якщо твір виконується в приміщенні (хата, клуб тощо), колектив співає тихо, не напружено, в середньому регістрі, а підголосок виконується у високому-головному регістрі. Якщо ж музичний твір виконується на вулиці, колектив співає голосно, дещо напружено в низькому, грудному регістрі, підголосок також виконується в грудному регістрі. Робочий діапазон основної мелодії в першому випадку майже ніколи не виходить за межі середнього регістру, а в другому - грудного. Так, під час виконання одного й того самого твору колектив може надавати йому різного змісту й форми (змінювати тональність, динаміку, темп, характер виконання тощо) [3].

У цьому контексті цікавою є виконавська практика етнографрічного хору «Гомін» імені Леопольда Ященка. Колектив має мобільний склад виконавців, котрий часто змінюється, артисти переважно не мають музичної освіти, проте за рахунок виконавського досвіду народнопісенної імпровізації колектив зберігає якісні мистецькі показники. Народні пісні у виконанні етнографрічного хору «Гомін» ім. Л. Ященка створюються та набувають свого поширення в межах повсякденного побуту [2]. Такі колективи, як хор «Гомін», мають першочергову мету - збереження традиції побутового співу, що, у свою чергу, зумовлює бажання співати «для себе». Цю особливість народного хорового співу відзначив Л. Куба: «Народний хор співає тільки для себе і аж ніяк не для кого іншого... Для народу значно приємніше, коли він нехай і не цілком досконало, співає сам, ніж коли слухає найдосконаліший спів» [1].

Проте, коли самодіяльна імпровізаційна пісня потрапляє на концертну естраду, її мета й функції зазнають змін: на концертній естраді вона призначена в основному для сприйняття аудиторією. Концертна сучасна естрада $€$ фрактично новою фрормою життя самодіяльної народної пісні. Так, концертне виконання висуває нові вимоги до народної пісні, і не кожна пісня може їх задовольнити у своєму первісному вигляді. За фрормою та змістом ліричні протяжні пісні, котрі мають розгорнутий, багатоповторюваний літературний текст, $€$ небезпечними для сценічного виконання й містять ризик втрати глядацької цікавості. Така тенденція зумовлена такими критеріями: куплетна форма твору з повторюваним приспівом у повільному темпі зумовлює (в самодіяльному хорі) сповільнення темпу, нерозбірливу вимову тексту, втрату загальної композиційної сюжетної цілісності. 3 боку вокально-хорових критеріїв $€$ ризик демонстрації примітивного одноманітного мелодичного малюнку та голосоведення, як, наприклад, деякі старовинні обрядові пісні: весільні, колядки, веснянки тощо. Такі пісні найдоцільніше використовувати під час створення театралізованих вокально-хореографічних, обрядових дійств, коли спів поєднується 3 танцем, розмовними епізодами, сценічним рухом тощо. До цього ж варто додати, що на концертній естраді хорові пісні виконуються переважно організованими й навченими колективами, які мають набагато більші виконавські можливості, ніж поширені в побутовій традиції стихійні гурти, склад яких рідко перевищує 10-15 виконавців. Ці недоліки систематично зустрічалися в процесі концертної діяльності хору «Гомін» за умови недоцільного добору концертного репертуару. Така ситуація потребує належної уваги керівника та його беззаперечного авторитету в питанні як добору концертної програми, трансорормації музичного твору (обробка, аранжування) відповідно до сталого складу виконавців, так і процесу імпровізаційності та сценічної виконавської інтерпретації [2].

Отже, виникає потреба в пристосуванні пісень до нових умов, у редакції та обробці їх для концертного виконання. Тобто майже всі хорові обробки та гармонізації народних пісень, здійснювані, зокрема, Леопольдом Ященком, є, по суті, концертними обробками, адже вони призначені переважно для концертного виконання [4].

Аналізуючи народні пісні, композитори зазвичай ставлять перед собою такі завдання: глибше розкрити за допомогою засобів професійного мистецтва їх зміст, настрій і характер, краще донести їх до слухача, а разом із тим повніше використати багаті виражальні можливості організованого хорового колективу. Виходячи 3 характеру пісенної мелодики та сюжету, композитори часто вдаються до різноманітних мелодичних, ритмічних і тембрових контрастів, які оживають і збагачують дещо одноманітне звучання куплетної форми. Отже, всі хорові обробки можна розділити на такі три види: гармонізацію, або розкладку, пісні, обробку в куплетно-варіаційній фрормі з незмінною мелодією й вільну оброку. Існують також і проміжні види обробки. Зазначимо, що такий поділ досить умовний, адже, наприклад, між розвиненою куплетно-варіаційною фрормою та вільною обробкою чіткої межі немає. Одним із показових майстрів обробки народної пісні є Л. Ященко. Його обробки та гармонізації пісень можна визначити як такі, що призначені для виконання самодіяльним хоровим колективом, орієнтовані на склад і виконавські можливості етнографрічного хору «Гомін», де в разі потреби легко внести незначні зміни без утрати загальної форми та музично-естетичного 
контексту. Оскільки для артистів самодіяльного хору спів $є$ передусім хобі, часто керівники повинні вирішують проблему відсутності повного якісного складу тих чи інших партій, легка та гнучка стилістика хорової обробки суттєво поліпшує якість виконання [4].

Після проголошення Незалежності України «Гомін» співає й на багатолюдних майданах, і у військових частинах, і на великій сцені, що відображено й у вокально-хорових і зовнішньоестетичних виконавських критеріях колективу. Так, постає потреба пошуку компромісних рішень, котрі якісно впливатимуть на виконавську практику, але залишатимуть провідною метою збереження творчої фрілософрії та мистецької волі самодіяльного хорового колективу, зокрема такого відомого колективу, як «Гомін», де протест і воля є одним із головних постулатів колективу. Так, зберігаючи власний авторитет керівника, наставника, вчителя, Л. Ященко вдало поєднував мету розвитку й популяризації народнопісенних виконавських традицій і роботу над якістю музичних, вокальнохорових показників. Попри педагогічну мудрість і лояльність Л. Ященка, концертні виступи під його орудою можна визначити як такі, що відповідають як виконавським, так і зовнішньоестетичним критеріям. Проте молодим керівникам самодіяльних хорових колективів важливо звертати належну увагу на відповідність виконавського процесу й зовнішніх естетичних показників сучасним вимогам, що висуваються суспільством до активно концертуючих колективів. Часто керівниками самодіяльних хорів продовжують бути їх засновники, проте в процесі спадкоємності поколінь важливо, щоб молодий фрахівець грамотно ставився до напрацювання авторитету серед артистів хору й лояльного впровадження сучасних митецьких процесів у діяльність аматорського хору. У разі відсутності достатнього авторитету керівника несприйняття виконавцями новітніх сучасних мис- тецьких тенденцій доречно прогнозувати занепад жанру самодіяльних хорів, що суттєво погіршить специфріку збереження локальних регіональних народнопісенних виконавських традицій.

Висновки. Хоровий спів є найбільш демократична форма художньої творчості соціуму, адже спонукає до активної творчої діяльності й містить значні виховні та організаційні можливості. Хоровий спів є одним із важливих і дієвих засобів виховання та фрормування художнього смаку й загальної музичної культури соціуму. Отже, повноцінне естетичне виховання соціуму передбачає також і безпосередню участь у творчому оволодінні навичками колективного та індивідуального виконання музичних творів. Отже, високі вимоги, що висуває до народної пісні науковий і технічний прогрес, зумовлюють модернізацію сценічного відтворення народнопісенної традиції, що, у свою чергу, потребує належних трансорормацій жанру в поєднанні зі збереженням регіональних виконавських традицій, адже учасники самодіяльних хорів здебільшого є носіями цих традицій, а тому й носіями національної мистецької самобутності.

\section{БІБЛІОГАФІЧНИЙ СПИСОК:}

1. Бермес І.Л. Український хоровий рух у контексті соціокультурних процесів XIX - початку XXI століття : авторефр. дис. ... докт. мистецтвознавства : 26.00.01 / Нац. акад. кер. кадрів культури і мистецтв. Київ, 2014. 36 с.

2. Гуць М. Прапороносець відродження українського народного співу у Києві (до 75-річчя від дня народження Леопольда Ященка). Народна творчість та етнографрія. 2003. № 4. С. 35-46.

3. Скопцова О.М. Формування організаційних, художніх та стилістичних особливостей українського народного хорового виконавства кінця XIX - першої третини XX ст. Вісник Міжнародного слов'янського університету. Серія «Мистецтвознавство». 2006. № 1. C. 39-42.

4. Сможаник О. Джерела української хорової культури. Молодь і ринок. 2011. № 11. С. 127-131. 